Kubiczek A., Shadow economy as an example of unfair competition, „Ekonomia i Prawo. Economics and Law.", Polszakiewicz B., Boehlke J. (ed.), Vol. 13, No. 3/2014, pp. 449-463. DOI: http://dx.doi.org/10.12775/EiP.2014.032.

\author{
AgATA KUBICZEK*
}

\title{
SHADOW ECONOMY AS AN EXAMPLE OF UNFAIR COMPETITION
}

\author{
SUMMARY
}

The article presents the basic problem of economics - competition. This problem is connect with shadow economy.

In the first part indicated on the essence and the kinds of business competition. Then focus on unfair competition in the form of shadow economy and how to fight it. The aim of this article is to identify the most important ways to reduce unfair competition.

Keywords: economics, competition, shadow economy

JEL Classification: E26, K42, L51, O17

\section{INTRODUCTION}

In the contemporary world, competition is omnipresent and involves all aspects of human activity (including business). Companies, for obvious reasons, would rather not participate in competitive struggles. If competition is exercised in accordance with law, without breaching the rules and regulations of a given market, there is no need to worry. However, business prac-

* Agata Kubiczek, Nicolaus Copernicus University, Faculty of Economics Sciences and Management, Department of Economics, ul. Gagarina 13A, 87-100 Toruń, phone: +48 56611 46 23, e-mail: agatak@econ.umk.pl. 
tice shows that companies often compete with each other with no regard for any rules and regulations.

The article presents selected aspects of business competition. In the first part, the essence and the kinds of business competition have been demonstrated. Next, the focus was on unfair competition, such as the shadow economy, and the ways to fight it. The shadow economy, which constitutes a substantial part of unfair competition contributes significantly to the business risk taken by legally functioning enterprises. It is for this reason that both companies who operate legally and particular governments, try to tackle the issue. The aim of the article is to point to the most important ways to limit unfair competitive advantage.

\section{THE ESSENCE AND THE KINDS OF BUSINESS COMPETITION}

The problem of competition appears wherever there are limited resources, and at least two parties which are interested in acquiring them. We can make a statement that competition, which is associated with all aspects of business activity, is one of the fundamental issues of Economics. From the economic point of view, competition can be defined as a phenomenon characteristic of a free-market economy, resulting from the presence of numerous players on the market in the areas of supply and demand.

According to $\mathrm{H}$. Adamkiewicz-Drwiłlo, competition is a rivalry between the participants of the market game, who aim at making a profit or achieving success by promoting better offers ${ }^{1}$.

M.J. Stankiewicz believes that competition is a phenomenon whose participants fight each other in pursuit of analogical goals, which means that the actions taken by some of them in order to reach a given goal make it more difficult (or in some cases impossible) for the goal to be reached by others ${ }^{2}$. Competition can take a form of a struggle or a game.

In fact, the factor which can be perceived as the essence of competition is rivalry, a competitive fight according to specific rules, whose goal is to fulfill given objectives. It means that the participants of a competitive fight have similar objectives.

The term 'fight' refers to various types of actions, which can involve:

${ }^{1} \mathrm{H}$. Adamkiewicz-Drwiłło, Uwarunkowania konkurencyjności przedsiębiorstw, PWN, Warszawa 2002, p. 65.

2 M.J. Stankiewicz, Konkurencyjność przedsiębiorstwa. Budowanie konkurencyjności przedsiębiorstwa w warunkach globalizacji, Dom Organizatora TNOiK, Toruń 2002, p. 18. 
- a clash of opponents, who are hostile, hateful of contemptuous towards each other, and aim at destroying their rivals;

- a clash of opponents who are aware of the existing antagonism, but feel no hatred towards each other, who interfere with each other's actions in order to achieve the same resource ${ }^{3}$.

The first type of the competitive fight occurs rarely, as it breaches elementary moral norms. Not only in business, competitive fight is usually regulated. The fighting knights have created their code (a set of rules for their combat), and similarly athletes also compete against each other in accordance with the accepted rules ${ }^{4}$.

In a competitive fight, the point is to create obstacles for the rivals, making it more difficult or impossible for them to reach a given goal. Disturbing one's competitors can take a number of forms. One of them is hindering their entry to the market, for instance by lowering the prices to the level which eliminates rivals, falsifying information, industrial espionage and so called hostile takeovers of competing companies. According to B. Klimczak, 'the forms of creating obstacles for competition are unacceptable, as they are aimed at weakening, or eliminating competition, and transforming the situation into a monopoly, and thus threaten economic freedom'5 . As B. Klimczak notices, another problem can be observed here: to determine if barring a competitor from entering a given market is intentional of unintentional? (what a company's intention is in such case?) ${ }^{6}$.

We can also analyze the following question: can competition have its limits? Are there situations in which limiting competition, or replacing it with a state or a monopoly would turn out to be a better solution? Positive responses to the question can be found in the literature on the subject. There are structural limitations on excessive competition, which is why it is unable to solve such problems as:

- socio-economic differences within countries and between them;

- marginalization of social life in many parts of the world;

- exploitation and destruction of systems essential for the life of our planet (ecology-related problems);

${ }^{3}$ B. Klimczak, Etyka gospodarcza, Wydawnictwo Akademii Ekonomicznej we Wrocławiu, Wrocław 2006, p. 102-103.

4 Ibidem, p. 103.

5 Ibidem, p. 103.

6 Ibidem, p. 103-104. 
- concentration of power in highly unsuitable business units, such as transnational corporations, global information and communication networks ${ }^{7}$.

Apart from that, competition can be eradicated by a monopolized form of the market. It is related, among other factors, to creating competitive advantage by lowering $\operatorname{costs}^{8}$. Despite being considered one of the best means of exchanging resources and goods in the economy, competition has numerous limitations. It is still, however, a better solution than a state's firm intervention, manifested by the existence of political pressure groups and lack of knowledge concerning the economic development. Such a faulty policy of a state will inevitably lead to a stagnation and crisis in the economy ${ }^{9}$. Limiting it, and thus promoting liberty, entrepreneurship and competitiveness leads to a better economic situation.

Depending on the chosen criterion of division, numerous types of competition can be found in economic literature. We can talk about a price- and non-price competition ${ }^{10}$. The division suggests that from the competition's point of view the price if of primary importance, with other factors (such as quality) being secondary.

Another criterion of division which is popular in academic literature is perfect and imperfect competition ${ }^{11}$. The criterion of this division is based in the ability of particular business entities to influence the whole market, which means that:

- we can talk about perfect competition if there is a large number of buyers and sellers, with none of them having direct influence on the prices and demand;

- imperfect competition occurs when there are business entities which can influence the prices and demand.

Another example of division which seems relevant from the point of view of companies' competitiveness is the division between fair and unfair competition. What is important here is clear definition of the methods of conduct and the tools given business entities use. We can here be dealing with possible examples of breaking the economic, civil or criminal law on one hand, and a failure to comply with the rules of business ethics on the other ${ }^{12}$.

7 Grupa Lizbońska, Granice konkurencji, Poltext, Warszawa 1996, p. 19.

${ }^{8}$ M. Porter, Porter o konkurencji, PWE, Warszawa 2001, p. 109.

9 L. Balcerowicz, Państwo w przebudowie, Znak, Kraków 1999, p. 14-16.

${ }^{10}$ B. Klimczak, Mikroekonomia, Wydawnictwo Akademii Ekonomicznej we Wrocławiu, Wrocław 2006, p. 313.

11 Ibidem, p. 232-311.

${ }^{12}$ H. Adamkiewicz-Drwiłło, op. cit., PWN, Warszawa 2002, p. 72. 
From the point of view of business competition, it is also important to define the area within which the competition takes place. The area of competition is traditionally defined as the market on which the rivalry takes place. The market can be understood in very broad terms, as the term can refer to the global, national or local market. Regardless of the market's size, we can at the same time be dealing with the two abovementioned types of competition, the perfect and imperfect one.

Although it is the market that is the primary area of competition, it is worth noting that competition outside the market is equally important, playing an increasingly important role in the times of various areas of economic and social overlapping each other. Competition outside the market will occur wherever companies decide to undertake actions aimed at particular economic effects, like creating an opinion in the eyes of potential buyers by supporting various social and charity events.

\section{UNFAIR COMPETITION}

If a rivalry takes place in accordance with fixed rules, it is referred to as fair competition. Fairness is then acting with respect for the commonly accepted norms. Thus, fairness is actually characterized by its opposite: competition is unfair when it breaches the commonly accepted norms. Thus, the participants in the market need to agree on what rules of competition are meant to be like ${ }^{13}$.

Communities involved in economic activity will make attempts in order to determine which means of competitions are undesirable. The primary legal act which regulates the issues of unfair competition in Poland is the Unfair Competition Act from 16th April $1993^{14}$. According to the act, unfair competition is acting against the law or good customs, if it threatens or breaches the interests of other entrepreneur or client ${ }^{15}$.

An important piece of evidence for the existence of unfair competition is the shadow economy. It is often referred to as informal, or underground economy. The shadow economy is defined as the unregulated, undeclared part of economic activity expressed as the percentage of $\mathrm{GDP}^{16}$. It is also the result

${ }^{13}$ B. Klimczak, Etyka ..., op. cit., p. 104.

${ }^{14}$ Act of 16 April 1993 On combating unfair competition, Journal of Laws No. 03.153.1503.

15 Ibidem, art. 3.1.

${ }_{16}$ T. Packard, J. Koettl, C.E Montenegro, In From the Shadow. Integrating Europe's Informal Labor, The World Bank, Washington 2012. 
of failing to comply with the rules set for the socio-economic game ${ }^{17}$. Limiting the size of shadow economy, even partial, would be of utmost importance for the economy, especially for the state's budget revenue ${ }^{18}$.

Due to the difficulty with estimating the size of shadow economy, the Polish institutions (Central Statistical Office - GUS), as well as international ones (the European Commission, OECD), include only unregistered labour to it. Thus, they do not take into account criminal activities (so called black economy). GUS considers unregistered labour to be: paid employment without any written contract between the employer and the employee, as well as untaxed work for one's own profit ${ }^{19}$.

Informal economy occurs in all countries. National borders are not an obstacle for it, and it often transforms into criminal activity.

In Europe in 2013, the shadow economy was estimated to be 2.15 trillion euro ${ }^{20}$. Of course, in various European countries the shadow economy occurs to varying extents (the amount is usually presented as the percentage of GDP). For example, in Germany and France the shadow economy constitutes about $13 \%$ of the countries' GDP, whereas in Switzerland and Austria it is estimated to be about $8 \%$ of GDP, reaching as much as $30 \%$ of GDP in the countries of Central and Eastern Europe, such as Bulgaria, Croatia, Lithuania or Estonia ${ }^{21}$.

In Poland, according to the report by Friedrich Schneider and the research team of A.T. Kearney, 25\% of GDP is produced within the shadow economy ${ }^{22}$. The share of informal economy in Poland, in relation to the data presented is at the medium level. In comparison to the countries of Central and Eastern Europe Poland ranks better (Table 1). In those countries, the shadow economy is more popular and more widely accepted by the population.

17 G. Gołębiewski, Zjawisko szarej strefy z uwzględnieniem gospodarki polskiej, „Współczesna Ekonomia", No. 1/2007.

${ }_{18}$ M. Polasik, J. Marzec, P. Fiszeder, J. Górka, Modelowanie wykorzystania metod platności detalicznych na rynku polskim, „Materiały i Studia NBP”, No. 265/2012.

19 B.S. Frey, F. Schneider, Ekonomika gospodarki nieformalnej, [in:] A. Karwińska, A. Surdej (ed.), Wokót zagadnień gospodarki nieformalnej, Wydawnictwo AE w Krakowie, Kraków 2004, p. 16; GUS, Praca nierejestrowana w Polsce w 2004 roku, Warszawa 2005, p. 7-9.

${ }^{20}$ F. Schneider, A.T. Kearney, The Shadow Economy in Europe, 2013, Johannes Kepler Universitat, Linz 2013, p. 3.

${ }^{21}$ F. Schneider, A.T. Kearney, The Shadow Economy in Europe, 2011, Johannes Kepler Universitat, Linz 2011, p. 1.

${ }^{22}$ Ibidem, p. 3. 
Table 1. The size of the shadow economy in selected European countries (in 2010)

\begin{tabular}{|c|c|c|c|}
\hline COUNTRY & $\begin{array}{l}\text { GDP (MILLIONS } \\
\text { OF EUROS) }\end{array}$ & $\begin{array}{l}\text { SHADOW ECONOMY } \\
\text { (MILLIONS OF EUROS) }\end{array}$ & $\begin{array}{c}\text { SHARE OF SHADOW ECONOMY } \\
(\% \text { OF GDP })\end{array}$ \\
\hline Germany & 2477 & 344 & 14 \\
\hline France & 1933 & 281 & 11 \\
\hline Great Britain & 1697 & 182 & 11 \\
\hline Holland & 588 & 59 & 10 \\
\hline Switzerland & 399 & 32 & 8 \\
\hline Belgium & 353 & 61 & 17 \\
\hline Sweden & 347 & 52 & 15 \\
\hline Austria & 286 & 23 & 8 \\
\hline Italy & 1549 & 338 & 22 \\
\hline Spain & 1063 & 206 & 19 \\
\hline Greece & 230 & 58 & 25 \\
\hline Turkey & 554 & 157 & 28 \\
\hline Poland & 353 & 90 & 25 \\
\hline Czech Republic & 145 & 24 & 17 \\
\hline Romania & 122 & 36 & 30 \\
\hline Hungary & 98 & 23 & 23 \\
\hline Slovakia & 35 & 9 & 24 \\
\hline Bulgaria & 36 & 12 & 33 \\
\hline Lithuania & 27 & 8 & 30 \\
\hline Estonia & 14 & 4 & 29 \\
\hline
\end{tabular}

Source: own study on the basis of: F. Schneider, A.T. Kearney, The Shadow Economy in Europe, 2011, Johannes Kepler Universitat, Linz 2011, p. 3.

The analysis of data describing informal economy (Table 1), a conclusion can be drawn that the higher a given economy's level of development, the smaller the share of informal economy. M. Kabaj, however, proves that there are exceptions from this rule ${ }^{23}$.

The main reasons for the existence of the shadow economy are:

- lack of possibilities for formal employment;

${ }_{23}$ M. Kabaj, Praca nierejestrowana we wspótczesnej literaturze ekonomicznej, „Polityka Społeczna”, No. 10/2009, p. 8-9. 
- relatively high taxes (and social security insurance contributions) in the official economy ${ }^{24}$;

- the decrease in the population's real income;

- the fear of losing welfare benefits after registering one's job contract (in case of, for example, pensioners and the unemployed);

- excessive supply of labour force (national and foreign) with free time;

- overly complicated administrative procedures, which hinder economic activity (meaning not only difficulties with filling administrative forms, but also too intensive legal regulations ${ }^{25}$;

- the drop in so called 'tax morale' and

- relatively low risk of functioning in the shadow economy ${ }^{26}$.

Recently, in academic literature another reason for the existence of the shadow economy is pointed to- cash. It is so, because cash is anonymous and easy to use. Limitations of the shadow economy should be also attributed to the development of electronic payments (e-payments) ${ }^{27}$.

The shadow economy phenomenon is dangerous to the economy, as it limits the official amount of means of production, weakens the economy's effectiveness and the society's trust towards the state, as well as limits the expenses taken by the state for welfare programs.

It is worth here that academic literature occasionally perceives the existence of the informal economy as a positive phenomenon. It is claimed that the shadow economy is beneficial, as it satisfies the demand for certain services and goods in a given economic environment. The informal sector contributes to the spirit of entrepreneurship in the economy, and is capable of reinforcing competition and raising efficiency. The informal sector contributes to the creation of markets, increases financial assets and reshapes legal, social and business institutions. What is more, a substantial part (up to 70\%) of the income gained in the shadow economy is quickly spent in the official sector,

${ }^{24}$ In Poland, it is a so called tax wedge, which refers to the situation in which the total cost of legal employment taken by the employer is a double of what an employee actually earns, which serves as an incentive to pay the whole, or a part of an employee's wages in an informal way. It allows for lowering the cost, in order to withstand the competition.

25 Sometimes the only way to employ a sufficient number of workers quickly and inexpensively is informal employment (often employing foreigners)

${ }^{26}$ F. Schneider, Shadow Economies and Corruption All Over the World: What Do We Really Know?, Discussion Paper No. 2315, Johannes Kepler University of Linz and IZA, Bonn 2006; GUS, Praca nierejestrowana w Polsce w 2004 roku, op. cit.

${ }^{27}$ European Central Bank, Single Euro Payments Area. Seven Progress Report. Beyond theory and Practice, Frankfurt 2010. 
thus stimulating the official economy. The expenses usually result in an increase of consumption and (mostly indirectly) tax revenues ${ }^{28}$.

\section{WAYS TO REDUCE SHADOW ECONOMY}

The research carried out in Poland indicate that the biggest influence on the creation of informal economy is exerted by factors which are economic in their nature (lack of or insufficient income of the employed, lack of legal employment, the fear of losing welfare benefits in case of registering one's employment contract, lowering costs in order to meet the competition, etc. $)^{29}$. Paradoxically, one can say that one of the reasons for the growth of the informal economy is its existence in the first place.

However, the phenomenon of shadow economy is dangerous for companies themselves. The shadow economy, which is an important element of unfair competition increases the market risk and the financial risk of the companies which operate legally. It is for those reasons that both the companies operating legally, as well as particular governments, try to tackle the issue by means of appropriate legislation ${ }^{30}$.

The means of fighting the informal economy depend primarily on its type from the point of view of its legality. Thus we can distinguish:

- illegal production and services (forbidden by law) tackled by the police and customs officials;

- hidden production or services (permitted by law, but unregistered), tackled by fiscal agencies.

The activities within the shadow economy can be divided into three groups, depending on the extent to which it is tackled:

- activities which are always pursued, such as smuggling, production and drug trafficking, economic crimes and thefts on a large scale;

- activities pursued sporadically, after breaching some limit in terms of scale and duration, such as manufacturing alcohol at home, minor profiteering;

${ }_{28}$ B.S. Frey, F. Schneider, op. cit., p. 9.

29 GUS, Praca nierejestrowana w Polsce w 2004 roku, op. cit.; GUS, Praca nierejestrowana w Polsce w 2010 roku, Warszawa 2011; M. Grabowski, Nielegalne zatrudnienie w MSP w Polsce, [in:] PARP, Pracodawcy-pracobiorcy w sektorze prywatnym, Warszawa 1997.

30 The aforementioned Act of 16 April 1993 On combating unfair competition, can serve as an example here. 
- activities not pursued, like private lessons, or minor repairs made by neighbors ${ }^{31}$.

In literature concerning the topic, two main means of tackling informal economy are distinguished:

- decreasing the cost of official activity, which means reducing the costs taken by registered companies by means of limiting legal and economic regulations, and reducing taxes and fees;

- increasing the costs of operating within the shadow economy by increasing the efficiency of fiscal agencies, imposing financial penalties for illegal or unregistered turnover ${ }^{32}$.

The first way means decreasing the state's interference into the economy. In Poland at present, despite the officially declared will to liberalize the economy, a large number of regulations and limitations exist, such as licenses and permits, as well as overly regulated labour market. The fiscal system is also an important factor here. It is evident that a system complicated with high tax rates, encourages the risk of getting involved in operating in the shadow economy, even with relatively high fines, whereas a simple system with low taxes reduces the costs of state administration, as well as the costs of running a company, at the same time reducing the tendencies for unregistered activity. An additional drawback of the Polish system is the lack of stable regulations.

The second way of limiting informal economy is mostly connected with the organization and functioning of fiscal and customs agencies, as well as various types of inspection (National Labour Inspectorate, building sites inspectors etc.). In Poland, the structure of those agencies is imperfect, they are insufficiently equipped with legal and material means (like computers etc.), as well as insufficiently staffed. Apart from that, the regulations, including legal acts, are in many aspects unclear, or even contradictory. What could also be mentioned here is the negative attitude towards fiscal agencies. The media are keen on scrutinizing the mistakes made by tax offices, with cheating on the fiscal system committed by entrepreneurs being mostly neglected. In addition, the Poles still tend to be proud of such cheating, unlike the rich countries, where the source of pride is the amount of taxes paid ${ }^{33}$.

Another possible solution may be minimalizing the circulation of cash in the economy, which may contribute to the decrease in the size of the shadow economy. In economic reality the following dependence can be ob-

31 B. Bachowska, K. Górka, Sposoby ograniczania oszustw podatkowych w Polsce, [in:] A. Karwińska, A. Surdej (ed.), Wokót zagadnień gospodarki nieformalnej, Wydawnictwo AE w Krakowie, Kraków 2004, p. 161.

32 Ibidem, p. 162.

33 Ibidem, p. 171. 
served: the bigger the market of electronic payments, the smaller the shadow economy of a country. The Scandinavian countries can serve as an example here. The limiting of shadow economy can be attributed to the development of electronic payments (e-payments). The e-payments made by means of pay cards leave a 'trace', which allows to collect information concerning the parties of a given transaction. However, the development of electronic payments in the Polish economy encounters numerous obstacles, which are mostly poor infrastructure and the society's reluctance towards them ${ }^{34}$.

From the economy's point of view (macro), as well as from the point of view of particular companies (micro), cash generates particular costs. It is estimated that the transition from the financial system based on cash to the one based exclusively on electronic payments would allow for savings in the economy in the amount of about $1 \%$ of GDP ${ }^{35}$. According to the estimates of the European Commission, the aggregate cost for the payment system of the European Union is 2-3\% of GDP. However, in some countries, such as Sweden or Holland, the cost of payment services is lower and amounts to $0.3-0.5 \%$ of GDP. The main determinant of the cost of the payment system is the use of cash, which is about $60-70 \%$ of the total cost. The lower cost in the Benelux and the Scandinavian countries results from the effective use of electronic payment tools ${ }^{36}$. In reference to the Scandinavian countries, it is worth noting that the process of quick elimination of banknotes and coins is especially visible there. In 2008, in Finland, Norway and Sweden ${ }^{37}$ the share of cash payments oscillated below $50 \%{ }^{38}$.

${ }^{34}$ NBP, Obrót bezgotówkowy - zalety i korzyści z jego upowszechnienia, Warszawa 2008.

${ }_{5}$ D.D. Garcia-Swartz, R.W. Hahn, A. Layne-Farrar, The move Towards a Cashless Society: A Closer Look at Payment Instrument Economics, „Review of Network Economics”, Vol. 5, No. $2 / 2006$.

${ }^{36}$ J. Haande, S. Oosterloo, D. Schoenmaker, European Financial Markets and Institutions, Cambridge University Press, Cambridge-New York 2009.

${ }^{37}$ In reference to Sweden, the opinion can be encountered that it will be the first European country where payments will be made only by electronic means. At present, in most cities of the country cash is not accepted in the means of public transport. In Sweden there are also cities where banks do not accept/pay out cash. A problem appears here concerning senior citizens, living in villages, who do not have credit cards, or simply cannot use them to pay out cash. In terms of instruments of electronic payment, it is worth noting that some churches in Sweden (Carl Gustaf Church in Karlshamn) have installed pay card readers in order for the members of congregation to make donations in this way. The process of substituting cash with e-payments in Sweden has also caused the number of bank robberies to fall from 110 in 2008 to 16 in 2011. On the other hand, the number of cyber-crimes (the cases of computerized frauds such as skimming) has increased from 3304 in 2000 to 20000 in 2011. For more see: The Huffington Post, Sweden Edges Closer to Becoming Cashless Society, http//www.huffingtonpost.ca (5.05.2013).

${ }^{38}$ M. Polasik, J. Marzec, P. Fiszeder, J. Górka, op. cit. 
Having the abovementioned facts in mind, the next step is the analysis of factors which would promote e-payments in the society (thus reducing the shadow economy). Four such factors can be distinguished:

- discouraging the circulation of cash. Easy access to cash slows down the transition into the system of electronic payments. Lack of commissions involved in withdrawing money from an ATM is in fact an incentive to bay with banknotes or coins at the points of sales;

- encouragement to pay at points of sales. A European makes on average 1 thousand payments a year, 80\% of which are cash payments. Those are mostly low-amount payments- below 15 euro. Using incentives, such as the decrease of VAT when making a card payment, or getting rid of additional fees for credit cards are good ways to change the prevailing attitude;

- an increase in the number of e-payments. The important initiator of electronic payments is the state (the public sphere). We can distinguish the following areas of supporting electronic payments: compulsory wage transfer to public employees' bank accounts; unemployed obtaining welfare benefits in the form of pre-paid cards, taxes and other payments can be made online. For example, all government payments in South Korea are made in the electronic form;

- encouraging to create bank accounts. One of such incentives can be attractive interest on the account;

- extending the areas where pay cards are accepted. Accepting debit and credit cards in Europe is not yet widespread. Even in the countries with large POS numbers, such as Portugal or Turkey, there are areas of trading activity (like fast-food places in Portugal), where the process of adopting electronic forms of payment is very slow. The countries with limited POS numbers may make the first step towards encouraging $\mathrm{cu}-$ stomers to make cash-free payments by making it easier for them to pay. The areas of economy where there is a high percentage of low-amount payments and a high share of the shadow economy (such as bars) are a good place to initiate such actions ${ }^{39}$.

39 F. Schneider, A.T. Kearney, The Shadow Economy in Europe, 2011, op. cit. 
Table 2. Actions aimed at reducing the shadow economy

\begin{tabular}{|l|l|}
\hline \multicolumn{1}{|c|}{ GENERAL INITIATIVES } & \multicolumn{1}{|c|}{$\begin{array}{c}\text { ACTIONS AIMED AT WITHDRAWING CASH } \\
\text { FROM CIRCULATION }\end{array}$} \\
\hline Introducing appropriate legal regulations & Discouraging cash circulation \\
\hline Creating the 'awareness of being guilty' in the society & Extending the areas where pay cards are accepted \\
\hline Reducing bureaucracy & Encouraging to use POS \\
\hline $\begin{array}{l}\text { Developing programs of financial inclusion. } \\
\text { Reducing material gains resulting from functioning } \\
\text { in the shadow economy. }\end{array}$ & Encouraging to open cash deposits. \\
\hline
\end{tabular}

* Point of Sale terminals (POS).

Source: F. Schneider, A.T. Kearney, The Shadow Economy in Europe, 2010, Johannes Kepler Universitat, Linz 2010, p. 12.

\section{CONCLUSIONS}

Business competition is the area of economic life in which many moral dilemmas appear. Economists point to the value of competition as pure rivalry, but the attempts to regulate it usually end with enumerating the acts of unfair competition.

The shadow economy, as an example of unfair competition, should generally be limited and liquidated, apart from certain exceptions. What could serve as such exceptions could be services which are socially beneficial, and at the same time hard to locate and usually on a small scale (such as paid neighbor's help, care over the sick or elderly). The argument in favor of accepting some aspects of the informal economy is of economic nature (the costs of tackling it, which are too high in relation to the potential fiscal gains), as well as of social one (the improvement in the well-being of the unemployed or pensioners $)^{40}$.

State-initiated action aimed at reducing the shadow economy should primarily involve exploration of the areas which are especially prone to illegal actions (such as illegal employment in construction industry). Regular controls are of utmost importance here. The ultimate goal should be, first of all, to encourage registration of economic activity and, consequently, to encourage fair competition on the market.

40 B. Bachowska, K. Górka, op. cit., p. 160. 


\section{BIBLIOGRAPHY}

Act of 16 April 1993 On combating unfair competition, Journal of Laws No. 03.153.1503. Adamkiewicz-Drwiłło H., Uwarunkowania konkurencyjności przedsiębiorstw, PWN, Warszawa 2002.

Bachowska B., Górka K., Sposoby ograniczania oszustw podatkowych w Polsce, [in:] A. Karwińska, A. Surdej (ed.), Wokót zagadnień gospodarki nieformalnej, Wydawnictwo AE w Krakowie, Kraków 2004.

Balcerowicz L., Panstwo w przebudowie, Znak, Kraków 1999.

European Central Bank, Single Euro Payments Area. Seven Progress Report. Beyond theory and Practice, Frankfurt 2010.

Frey B.S., Schneider F., Ekonomika gospodarki nieformalnej, [in:] A. Karwińska, A. Surdej (ed.), Wokót zagadnień gospodarki nieformalnej, Wydawnictwo AE w Krakowie, Kraków 2004.

Garcia-Swartz D.D., Hahn R.W., Layne-Farrar A., The move Towards a Cashless Society: A Closer Look at Payment Instrument Economics, „Review of Network Economics", Vol. 5, No. 2/2006, http://dx.doi.org/10.2202/1446-9022.1094.

Gołębiewski G., Zjawisko szarej strefy z uwzględnieniem gospodarki polskiej, „Współczesna Ekonomia”, No. 1/2007.

Grabowski M., Nielegalne zatrudnienie w MSP w Polsce, [in:] PARP, Pracodawcy-pracobiorcy w sektorze prywatnym, Warszawa 1997.

Grupa Lizbońska, Granice konkurencji, Poltext, Warszawa 1996.

GUS, Praca nierejestrowana w Polsce w 2004 roku, Warszawa 2005.

GUS, Praca nierejestrowana w Polsce w 2010 roku, Warszawa 2011.

Haande J., Oosterloo S., Schoenmaker D., European Financial Markets and Institutions, Cambridge University Press, Cambridge-New York 2009.

Kabaj M., Praca nierejestrowana we wspótczesnej literaturze ekonomicznej, „Polityka Społeczna”, No. 10/2009.

Klimczak B., Etyka gospodarcza, Wydawnictwo Akademii Ekonomicznej we Wrocławiu, Wrocław 2006.

Klimczak B., Mikroekonomia, Wydawnictwo Akademii Ekonomicznej we Wrocławiu, Wrocław 2006.

NBP, Obrót bezgotówkowy - zalety i korzyści z jego upowszechnienia, Warszawa 2008.

Packard T., Koettl J., Montenegro C.E., In From the Shadow. Integrating Europe's Informal Labor, The World Bank, Washington 2012.

Polasik M., Marzec J., Fiszeder P., Górka J., Modelowanie wykorzystania metod ptatnosci detalicznych na rynku polskim, „Materiały i Studia NBP”, No. 265/2012.

Porter M., Porter o konkurencji, PWE, Warszawa 2001.

Schneider F., Kearney A.T., The Shadow Economy in Europe, 2010, Johannes Kepler Universitat, Linz 2010.

Schneider F., Kearney A.T., The Shadow Economy in Europe, 2011, Johannes Kepler Universitat, Linz 2011. 
Schneider F., Kearney A.T., The Shadow Economy in Europe, 2013, Johannes Kepler Universitat, Linz 2013.

Schneider F., Shadow Economies and Corruption All Over the World: What Do We Really Know?, Discussion Paper No. 2315, Johannes Kepler Univesity of Linz and IZA, Bonn 2006.

Stankiewicz M.J., Konkurencyjnośc przedsiębiorstwa. Budowanie konkurencyjności przedsiębiorstwa w warunkach globalizacji, Dom Organizatora TNOiK, Toruń 2002.

The Huffington Post, Sweden Edges Closer to Becoming Cashless Society, http//www.huffingtonpost.ca (05.05.2013). 